\title{
KARAKTERISTIK KELUARGA SAKINAH DALAM ISLAM
}

\author{
Siti Chadijah \\ st_chadijah@yahoo.com \\ (Mahasiswa Program Doktor Universitas Muhammadiyah Jakarta)
}

\begin{abstract}
Abstrak:
Karakteristik Keluarga sakînah adalah keluarga yang berawal dari rasa cinta (mawaddah) yang dimiliki oleh kedua suami-istri, kemudian berkembang menjadi kasih sayang (rahmah)di antara setiap keluarga ketika anggota keluarga tersebut semakin bertambah anggotanya, hingga terciptanya ketenangan dan kedamaian hidup. Terdapat faktor-faktor yang menjadi karakteristik dari keluarga sakinah, yaitu 1) lurusnya niyat (islâh al-niyyah) dan kuatnya hubungan dengan Allah (quwwa(tu) shilah bi(l)lâh), 2) kasih sayang (mawadah wa rahmah); 3) saling terbuka (mushârahah), santun, dan bijak (mu'âsyarah bi al-ma'rûf); 4) komunikasi dan musyawarah, 5) toleran (tasâmuh) dan pemaaf; 6) adil dan persamaan; 7) sabar dan syukur.
\end{abstract}

\section{Kata Kunci: Karakteristik, Keluarga, Islam}

\section{A. Pendahuluan}

Pesatnya arus globalisasi dan semakin canggihnya perkembangan ilmu pengetahuan dan teknologi telah memberikan dampak besar bagi kemajuan peradaban manusia. Namun sejalan dengan hal tersebut ekses negatif pun bermunculan di hadapan manusia, baik secara individual maupun secara kolektif. Ekses negatif dimaksud muncul dalam berbagai bentuk, misalnya kenakalan remaja, tawuran antarpelajar, penyalahgunaan narkotika, pergaulan bebas, penyimpangan seksual, dan meningkatnya jumlah pasien penyakit psikologis (seperti stress, depresi, atau stroke). Hal tersebut kemudian berpengaruh pula terhadap kemapanan dan tatanan masyarakat damai sebagaimana dicita-citakan oleh tujuan peradaban itu sendiri.

Pada gilirannya, ekses tersebut juga telah mengancam tatanan keluarga, sehingga fungsi keluarga menjadi sumir (kabur). Fenomena keluarga sebagai organisasi kemasyarakatan terkecil telah kehilangan ruh (esensinya), terutama jika tercermin dari fenomena ikatan keluarga yang diperankan oleh para selebritis, termasuk selebritis di Indonesia. Fungsi keluarga sebagai tempat curahan kasih sayang orang tua kepada anak, keluarga sebagai pijakan pendidikan awal seorang anak, dan keluarga sebagai tiang negara telah kehilangan elan vital-nya. Pendidikan anak lebih banyak dipercayakan kepada lembaga-lembaga formal, seperti sekolah, madrasah, pesantren, atau lainnya. Bahkan sebagian anak belajar kepada sesuatu yang anonimous (sumber yang tidak jelas), seperti televisi, film, buku, atau hal-hal lain yang tidak bersumber dari guru definitif dan tidak jelas menampilkan norma-norma yang bernilai positif.

Sebagai bukti lain dari pergeseran peran dan fungsi keluarga di atas adalah meningkatnya kekerasan dalam rumah tangga (KDRT), baik dalam bentuk kasus Kekerasan Terhadap Perempuan (KTP) atau Kekerasan Terhadap Anak (KTA). Upaya untuk meminimalisir ekses negatif globalisasi dan industrialisasi merupakan tugas bersama, baik secara individu maupun kolektif. Upaya untuk meminimalisir hal tersebut tidaklah cukup hanya dengan mengandalkan pihak tertentu saja atau mengandalkan pendidikan formal 
saja. Bahkan hal yang agaknya tidak mungkin adalah mempercayakan pendidikan agama di institusi sekolah, terlebih institusi-isntitusi pendidikan umum (seperti SD, SMP, SMU, dan PT) yang mengajarkan agama hanya berkisar sekitar 2-4 jam per minggunya. Selebihnya kebanyakan pembelajaran agama juga diarahkan pada hapalan dan atau pengetahuan tentang agama atau ilmu agama ${ }^{1}$. Oleh karena itu, salah satu alternatif yang harus ditempuh adalah mengukuhkan kembali peran keluarga dalam pendidikan anak. Dari perpaduan pendidikan formal di sekolah dan pendidikan dalam keluarga, anak akan tumbuh menjadi orang yang baik dan pandai. $^{2}$

Menurut Zakiyah Darajat, ${ }^{3}$ dalam pendidikan keluarga ini, orang tua sangat berperan dan mereka diminta tanggung jawab, komitmen, dan konsistensinya dalam pendidikan anak. Dengan demikian, tanggung jawab orang tua (keluarga) dalam pendidikan anak cukup signifikan, sebab keluarga merupakan lingkungan yang pertama kali bersentuhan dengan anak. Dari mereka pula lah, anak memperoleh pengetahuan, pengalaman, keterampilan, dan sikap. Oleh karena itu, kualitas orang tua dan lingkungan keluarga sangat dominan dalam pembentukan jiwa dan kerpibadian anak.

Peranan dan tanggung jawab orang tua terhadap pendidikan anak secara eksplisit tergambar pada QS. al-Tahrîm (66):6.

\footnotetext{
${ }^{1}$ Azyumardi Azra, Pendidikan, Tradisi, dan Modernitas Menuju Milenium Baru, Jakarta, Logos, 1999, hlm. 3.

${ }^{2}$ Abd al-Rahmân al-Nahlawi, Pendidikan Islam di Rumah, Sekolah, dan Masyarakat, terjemahan oleh Sihabuddin, Jakarta, Gema Insani Press, 1995, hlm 27.

${ }^{3}$ Zakiyah Darajat, Berawal dari Keluarga: Revolusi Belajar Cara al-Qur'an, Jakarta, Hikmah, 2002, cetakan ke-1, hlm. Xi.
}

Ali bin Abi Thalib memaknai kata $q \hat{u}$ dalam ayat ini dengan didiklah dan ajari. Sedangkan Ibn Abbas menafsirkan makna kata tersebut dengan ajak dan serulah keluargamu untuk beramal dan beribadah kepada Allah serta hindari dan jauhkan mereka dari perbuatan maksiat. ${ }^{4}$ Sementara itu, Ibn Jarîr al-Thabarî $\hat{~}^{5}$ memaknai ayat itu dengan "bahwasanya setiap mukmin berkewajiban untuk mendidik diri dan keluarganya dengan ketaatan kepada Allah sehingga terhindar dari api neraka". Nabi Muhammad saw. Bersabda,

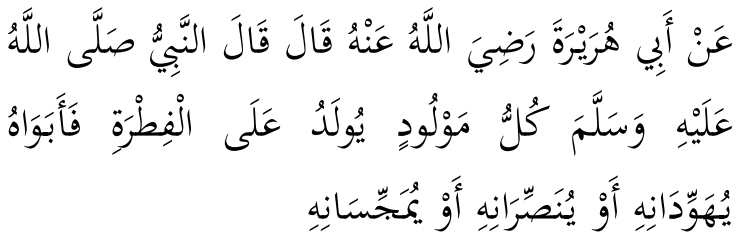

Dari Abu Hurairah r.a., Rasulullah bersabd, "Setiap anak dilahirkan membawa fithrah. Kedua orang tuanyalah yang menjadikan ia Yahudi, Nashrani, atau Majusi"'(HR. Bukhari dan Muslim). ${ }^{6}$

Tujuan pendidikan dalam keluarga tiada lain agar anak mampu berkembang secara maksimal, baik jasmani, akal, maupun ruhaninya. $^{7}$ Dengan perkembangan yang optimal tersebut diharapkan akan terbentuk kecerdasan anak dalam berbagai bentuknya. Akhirnya anak akan mampu berperan sebagai anggota masyarakat yang baik dan juga sanggup mempertanggung-jawabkan segala perilakunya sebagai khalîfat Allâh dan 'Abd Allâh. Untuk itu, orang tua dan

\footnotetext{
${ }^{4}$ Ibn Katsîr, Tafsîr al-Qur'ân al-'Adzîm, Beirut, Dâr al-Fikr, 1986, jilid IV, hlm. 392.

'Ibn Jarîr al-Thabarî, Jami' al-Bayân fîTa'wîl al-Qur'ân, Beirut, Dâr al-Fikr, 1988, jilid V, hlm. 156.

${ }^{6}$ Bukhari, Shahîh al-Bukhârî: Kitâb alJanâiz, Kairo, Dâr al-Hadîts, t. t. jilid II, hlm. 345; Muslim, Shahîh Muslim: Kitâb al-Qadr, Dâr alHadîts, t. t., jilid IV, hlm. 351.

${ }^{7}$ Abd al-Rahmân al-Nahlawi, Pendidikan Islam di Rumah, Sekolah, dan Masyarakat, terjemahan oleh Sihabuddin, Jakarta, Gema Insani Press, 1995, hlm 27.
} 
lingkungan keluarga harus mampu menciptakan lingkungan yang dapat menjamin berkembangnya seluruh potensi dan kemampuan seorang anak. ${ }^{8}$ Dengan demikian keluarga bukan hanya berfungsi sebagai ikatan biologis, tetapi juga mewujud sebagai tempat berlangusngnya pengajaran dan pendidikan bagi anakanaknya. Tentunya fungsi ini dijalankan sejak anak masih dalam kandungan (masa pra-natal) hingga masa dewasa. ${ }^{9}$

\section{B. Pengertian Keluarga Sakinah}

Munculnya istilah keluarga sakînah merupakan penjabaran dari QS al-Rûm (30):21 di atas. dalam ayat tersebut Allah menjelaskan bahwa tujuan diciptakannya seorang istri adalah agar suami dapat membangun sebuh keluarga sakinah yaitu keluarga yang harmonis, bahagia lahir batin, hidup tenang, tenteram, damai, dan penuh dengan kasih sayang. Istilah "sakinah" digunakan al-Qur'an untuk menggambarkan kenyamanan keluarga. Istilah ini memiliki akar kata yang sama dengan "sakanun" yang berarti tempat tinggal. Jadi, mudah dipahami memang jika istilah itu digunakan al-Qur'an untuk menyebut tempat berlabuhnya setiap anggota keluarga dalam suasana yang nyaman dan tenang, sehingga menjadi lahan subur untuk tumbuhnya cinta kasih (mawaddah wa rahmah) di antara sesama anggotanya.

Jadi, kata sakinah yang digunakan untuk menyifati kata "keluarga" merupakan tata nilai yang seharusnya menjadi kekuatan penggerak dalam membangun tatanan keluarga yang dapat memberikan kenyamanan dunia sekaligus memberikan jaminan keselamatan akhirat.

${ }^{8}$ Zakiyah Darajat, Berawal dari Keluarga: Revolusi Belajar Cara al-Qur'an, Jakarta, Hikmah, 2002, cetakan ke-1, hlm. Xi.

${ }^{9}$ A. K. Baihaqi, Mendidik Anak Dalam Kandungan, 1996, Jakarta, Raja Grafindo Persada,hlm. 18.
Rumah tangga seharusnya menjadi tempat yang tenang bagi setiap anggota keluarga. Keluarga menjadi tempat kembali ke mana pun anggotanya pergi. Mereka merasa nyaman di dalamnya, dan penuh percaya diri ketika berinteraksi dengan keluarga yang lainnya dalam masyarakat.

Dengan cara pandang itu, setiap keluarga dapat pastikan bahwa akar kasuskasus yang banyak melilit kehidupan keluarga di masyarakat adalah karena rumah sudah tidak lagi nyaman untuk dijadikan tempat kembali. Suami tidak lagi menemukan suasana nyaman di dalam rumah, demikian pula istri. Bahkan, anakanak sekarang lebih mudah menemukan suasana nyaman di luar rumah. Maka, sakînah menjadi hajat setiap keluarga. Sebab, sakînah adalah konsep keluarga yang dapat memberikan kenyamanan psikologis -meski kadang secara fisik tampak jauh di bawah standar nyaman.

Kata taskunu pada ayat di atas dikaitkan dengan kata mawaddah wa rahmah. Hal ini menunjukkan bahwa terwujudnya ketenangan keluarga didukung faktor mawaddah wa rahmah. Menurut Wahbah al-Zuhaili, mawaddah mengandung arti cinta, sedangkan rahmah berarti kasih sayang. Cinta dan kasih sayang merupakan unsur pokok yang mendorong suami istri mau saling membantu, menegakkan keluarga pada pondasi dan tatanan yang kuat dan melahirkan ketenangan yang sempurna. ${ }^{10}$ Berkaitan dengan mawaddah dalam arti kasih sayang, menurut Quraisy Shihab, kata mawaddah tersusun dari huruf $m-w-d$ $d$ yang artinya adalah kelapangan dan kekososngan jiwa dari kehendak buruk. Seseorang yang dalam hatinya telah bersemi mawaddah, maka ia tidak akan memutuskan hubungan, walaupun hatinya sedang kesal. Hal ini disebakan karena

${ }^{10}$ Wahbah al-Zauhaili, Tafsîr al-Munîr, Beirut-Libanon, Dâr al-Fikr, 1991, jilid XXI,hlm. 69. 
hatinya begitu lapang baik lahir maupun batin. Dengan kata lain, mawaddah adalah cinta plus. ${ }^{11}$

Di samping itu kata rahmah dilihat dari akar katanya merupakan verbal noun (mashdar) dari kata $r-h-m$. Dari kata asal ini terdapat kata-kata derivasi lainnya dalam al-Qur'an, yaitu rahima, arhama, marhamah, râhîm, rahmân, dan ruhm. ${ }^{12}$ Pada tingkat ini rahmah ini merupakan hubungan salin cinta antara dua orang lain jenis yang mampu mencapai kualitas kecintaan yang tidak terbatas, serba murni, dan sejati. Hubungan orang tua dengan anak dipersatukan dalam cinta istimewa yaitu rahim. Cinta anak kepada orang tua adalah cinta yang lebih dekat dengan cinta kasih kepada yang lainnya. Apalagi cinta orang tua, terutama cinta ibu kepada anaknya, merupakan cinta yang tulus dan murni. Inilah yang dinamakan rahim yaitu cinta kasih. Kasih sayang orang tua kepada anak dikatakan sebagai bagian dari naluri orang tua. Dalam situasi bagaimanapun orang tua akan senantiasa menyayangi anaknya, baik dalam keadaan senang maupun susah.

Dari keragaman pendapat di atas kiranya dapat disederhanakan bahwa keluarga sakînah adalah keluarga yang berawal dari rasa cinta (mawaddah) yang dimiliki oleh kedua suami-istri, kemudian berkembang menjadi kasih sayang (rahmah) yang setiap keluarga ketika anggota keluarga tersebut semakin bertambah anggotanya, hingga terciptanya ketenangan dan kedamaian hidup. Menurut Abdullah Gymnastiar, ${ }^{13}$ ada beberapa

\footnotetext{
${ }^{11}$ Quraisy Shihab, Wawasan al-Qur'an:

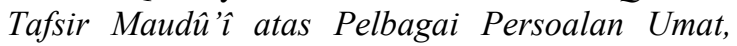
Bandung, Mizan, 1997, cet. Ke-5, hlm. 208.

${ }^{12}$ Dawam Raharjo, Ensiklopedi al-Qur'an: Tafsir Sosial Berdasarkan Konsep Kunci (Jakarta: Paramadina, 1996), cet. Ke-1, hlm. 212-213.

${ }^{13}$ Disarikan dari Abdullah Gymnastiar, Membangun Keluarga: 4 Visi Rumah Tangga sakinah Mawaddah wa rahmah, Bandung, MQS, Pustaka Grafika, 2002.
}

indikasi yang dapat menghantar-kan keluarga menjadi keluarga yang sakinah (bahagia). Pertama, dengan menjadikan keluarga yang ahli sujud, keluarga yang ahli taat, keluarga yang menghiasi dirinya dengan dzikrullâh, dan keluarga yang selalu rindu untuk mengutuhkan kemuliaan hidup di dunia, terutama mengutuhkan kemuliaan di hadapan Allah swt. kelak di surga. Jadikan berkumpulnya anggota keluarga di surga sebagai motivasi dalam meningkatkan amal ibadah.

Kedua, menjadikan rumah sebagai pusat ilmu. Pupuk iman adalah ilmu. Memiliki harta tetapi kurang ilmu akan menjadikan manusia diperbudaknya. Harta dinafkahkan akan habis, ilmu dinafkahkan akan melimpah. Pastikan agar setiap keluarga sungguh-sungguh untuk mencari ilmu. Baik ilmu tentang hidup di dunia maupun ilmu akhirat. Bekali anak-anak sedari kecil dengan ilmu dan jadilah orang tua yang senantiasa menjadi sumber ilmu bagi anak-anaknya.

Ketiga, jadikan rumah sebagai pusat nasihat. Setiap di antara angota kelurga harus tahu persis bahwa semakin hari semakin banyak yang harus dilakukan. Untuk itu setiap di antaa anggota kelurga harus sadar bahwa mereka butuh orang lain agar dapat melengkapi kekurangan guna memperbaiki kesalahan. Keluarga yang bahagia itu keluarga yang dengan sadar menjadikan kekayaanya saling menasehati, saling memperbaiki, serta saling mengkoreksi dalam kebenaran dan kesabaran. Setiap koreksian bahkan pujian yang diberikan oleh keluarga harus disyukuri. Hal ini karena mereka adalah bagian terdekat yang paling tahu apa yang dilakukan oleh anggota keluarga lainnya dalam kehidupan keseharian. Sehingga kritikan, koreksian, nasihat yang diberikan, dan bahkan pujian adalah lebih dekat pada keadaan diri yang sebenarnya.

Keempat, jadikan rumah sebagai pusat kemuliaan. Pastikan keluarga itu 
sebagai contoh bagi keluarga yang lain. Berbahagialah jika sebuah keluarga dijadikan contoh teladan bagi keluarga yang lain. Itu berarti, masing-masing anggota keluarga senantiasa menuai pahala dari orang yang berubah karena keluarga itu menjadi jalan kebaikan bagi yang lainnya. Saling berlomba-lombalah dalam memunculkan kemuliaan di keluarga.

\section{Unsur-Unsur Keluarga Sakinah}

Dari uraian di atas dapat dipahami bahwa ciri utama keluarga sakînah adalah adanya cinta dan kasih sayang atau mawadah wa rahmah dengan tujuan akhir adalah mardhatillâh. Hal ini sesuai dengan naluri manusia yang ingin memberikan dan menerima cinta kasih. Maka dalam keluarga sakînah, cinta dan kasih sayang benar-benar terjalin kuat, baik antara suami dengan istri atau sebaliknya, antara keduanya dengan anak-anaknya, serta antara anggota keluarga tersebut dengan keluarga yang ada di lingkungannya.

Dengan demikian, menurut penulis, terdapat faktor-faktor lain yang menjadi karakteristik dari keluarga sakinah, yaitu 1) Lurusnya Niyat (Islâh al-Niyyah) dan Kuatnya hubungan dengan Allah (Quwwatu shilah billâh), 2) kasih sayang; 3) saling Terbuka (Mushârohah), Santun dan Bijak (Mu'asyarah bil Ma'rûf); 4) komunikasi dan musyawarah, 5)Tasâmuh (Toleran) dan Pemaaf; 6) adil dan persamaan; 7). Sabar dan syukur. Secara umum dapat dikatakan bahwa keluarga sakinah dibangun di atas kasih sayang yang mengedepankan aspek komunikasi dan musyawarah sebagai bentuk dari pola hubungan demokratis yang menjadi sarana bagi terwujudnya komunikasi dialogis. Sehingga dengan adanya komunikasi tersebut tercapailah ketenangan, kedamaian, dan ketentraman dalam rumah tangga. Sedangkan musyawarah yang dipakai adalah musyawarah yang dihiasi dengan sikap lemah lembut, pemberi maaf, serta mengedepankan aspek keadilan dan persamaan. Beberapa konsep dasar di atas akan dijelaskan secara rinci di bawah ini.

1. Lurusnya Niyat (Islâh al-Niyyah) dan Kuatnya hubungan dengan Allah (Quwwatu shilah bi(a)llâh)

Motivasi menikah bukanlah semata untuk memuaskan kebutuhan biologis/fisik. Menikah merupakan salah satu tanda kebesaran Allah SWT sebagaimana diungkap dalam al-Qur'an (QS. al-Rûm (30):21), sehingga bernilai sakral dan signifikan. Menikah juga merupakan perintah-Nya (QS. al-Nur (24):32), yang berarti suatu aktifitas yang bernilai ibadah dan merupakan Sunnah Rasul dalam kehidupan sebagaimana ditegaskan dalam salah satu hadits, "Barangsiapa yang dimudahkan baginya untuk menikah, lalu ia tidak menikah maka tidaklah ia termasuk golonganku" (HR. alThabrani dan al-Baihaqi).

Oleh karena nikah merupakan sunnah Rasul, maka selayaknya proses menuju pernikahan, tata cara (prosesi) pernikahan dan bahkan kehidupan pasca pernikahan harus mencontoh Rasul. Misalnya saat hendak menentukan pasangan hidup hendaknya lebih mengutamakan kriteria al-dîn (agama/akhlaq) sebelum hal-hal lainnya (kecantikan/ketampanan, keturunan, dan harta); dalam prosesi pernikahan (walimat al-'urusy) hendaknya juga dihindari halhal yang berlebihan (mubâdzir), tradisi yang menyimpang (khurafât), dan kondisi bercampur baur (ikhtilâth). Kemudian dalam kehidupan berumah tangga pasca pernikahan hendaknya berupaya membiasakan diri dengan adab dan akhlaq seperti yang dicontohkan Rasulullah saw.

Menikah merupakan upaya menjaga kehormatan dan kesucian diri, artinya seorang yang telah menikah semestinya lebih terjaga dari perangkap zina dan mampu mengendalikan syahwatnya. 
Menikah juga merupakan tangga kedua setelah pembentukan pribadi muslim (syakhsiyah islamiyah) dalam tahapan amal dakwah, artinya menjadikan keluarga sebagai ladang beramal dalam rangka membentuk keluarga muslim teladan (usrah islami) yang diwarnai akhlak Islam dalam segala aktivitas dan interaksi seluruh anggota keluarga, sehingga mampu menjadi rahmatan $l i$ al âlamîn bagi masyarakat sekitarnya. Dengan adanya keluarga-keluarga muslim pembawa rahmat diharapkan dapat terwujud komunitas dan lingkungan masyarakat yang sejahtera.

Hubungan yang kuat dengan Allah dapat menghasilkan keteguhan hati (kemapanan ruhiyah), sebagaimana Allah tegaskan dalam QS. al-Ra'd (11): 28. "Ketahuilah dengan mengingat Allah, hati akan menjadi tenang". Keberhasilan dalam meniti kehidupan rumah tangga sangat dipengaruhi oleh keteguhan hati, ketenangan jiwa, yang bergantung hanya kepada Allah saja (ta'alluq bi(a)llah). Tanpa adanya kedekatan hubungan dengan Allah, mustahil seseorang dapat mewujudkan tuntutan-tuntutan besar dalam kehidupan rumah tangga. Kecintaan kepada keluarga, suami/istri, anak, dan lainnya hanya merupakan penjabaran perintah Allah. Muaranya adalah cinta kepada Allah, dan pengaruh positifnya terpancar dari cintanya kepada keluarga, suami/istri, anak dan lain-lain. Rasulullah bersabda,

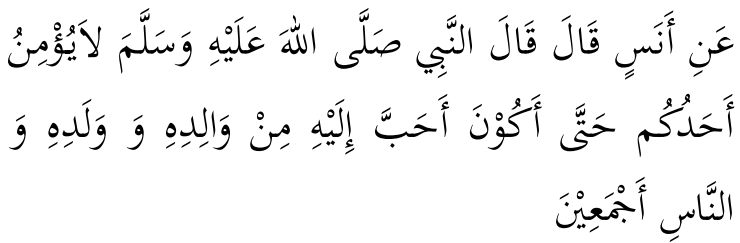

"Tdiak berimanlah seseorang di antara kalian sehingga kecintaannya kepada Allah (dan Rasul-Nya) melebihi kecintaan kepada orang tua, anaknya, dan seluruh manusia (H.R. Bukhari). ${ }^{14}$

Keteguhan hati dapat diwujudkan dengan pendekatan diri kepada Allah (taqarrub ila(a)llâh), sehingga ia merasakan kebersamaan Allah dalam segala aktifitasnya (ma'iyat(a)llâh) dan selalu merasa diawasi Allah dalam segenap tindakannya (muraqobat(a)llâh). Perasaan tersebut harus dilatih dan ditumbuhkan dalam lingkungan keluarga, melalui pembiasaan keluarga untuk melaksanakan ibadah nafilah secara bertahap dan dimutaba'ah bersama, seperti : tilawah, shalat tahajjud, shaum, infaq, do'a, ma'tsurat, dll. Pembiasaan dalam aktifitas tersebut dapat menjadi sarana menjalin keakraban dan persaudaraan (ukhuwah) seluruh anggota keluarga, dan yang penting dapat menjadi sarana mencapai taqwa dimana Allah swt menjamin orangorang yang bertaqwa.

\section{Kasih Sayang}

Qurasih Shihab menyatakan bahwa keluarga merupakan sekolah bagi setiap anggota keluarga. Landasan utama kasih sayang ini adalah saling mencintai karena Allah (mahabbah fi(a)llâh) antara suamiistri dan segenap anggota kelurga. Hal ini merupakan salah satu perekat terpenting dalam membangun keluarga sakinah dan merekatkan persahabatan di antara mereka. ${ }^{15}$ Munculnya cinta karena Allah Swt. disebabkan karena setiap anggota kelurga memiliki keimanan dan melakukan ketaatan-ketaatan kepada-Nya. Jika ada yang tidak disukainya dari salah satu anggota keluarga, hal itu karena ia tidak rela melihat salah satu anggota kelurganya melakukan kemaksiatan dan kemungkaran kepada Allah Swt. Rasulullah saw. bersabda,"Siapa saja yang memberi

\footnotetext{
${ }^{14}$ Bukhari, Kitâb al-Imân, Jilid I, hlm. 10.

${ }^{15}$ Quraish Shihab, Membumikan al-Qur'an: Fungsi dan Peran wahyu dalam Kehidupan Masyarakat, Bandung, Mizan, 2002, hlm. 255.
} 
karena Allah, menolak karena Allah, mencintai karena Allah, membenci karena Allah, dan menikah karena Allah, berarti ia telah sempurna imannya" (HR alHakim).

Dalam proses perwujudan keluarga sakinan dan pendidikan keluarga, ikatan kasih sayang antara anak dan orang tua ini mempunyai peran yang sangat penting. Curahan kasih sayang yang diberikan orang tua dapat menciptakan kesan yang sangat kuat di dalam hati dan benak anak. Persaaan kasih inilah yang berperan membentuk jiwa, sekaligus membangun kepribadiannya. Para pakar psikologi menjelaskan bahwa perasaan seorang anak kecil terhadap curahan cinta, respon, dan interaksi orang-orang di sekitarnya terhadap dirinya sangat penting dalam membantu pertumbuhan emosional dan kejiwaan, bahkan kecerdasan anak. ${ }^{16}$

Dalam keluarga yang penuh dengan cinta kasih ini, seorang anak akan memahami kehadiran dirinya sebagai suatu yang cukup menyenangkan dan diharapkan. Ia akan segera merasakan adanya ikatan yang menghubungkannya dengan orang-orang di sekitarnya. Ikatan dan hubungan yang terbangun atas dasar cinta itu selanjutnya menjadi dasar bagi anak dalam pembentukan pola hubungannya dengan orang lain. Sebaliknya, pola pendidikan yang dijalankan dengan cara menciptakan dan menumbuhkan perasaan takut, jauh dari cinta dan kelembutan hanya akan menciptakana dampak negatif dalam proses pembentukan kejiwaan dan emosional anak. Hal ini antara lain dapat berupa terlambatnya perkembangan fisik dan motorik, gagap atau gangguan bicara, sulit untuk berkonsentrasi, agresif dan nakal, kurang minat terhadap orang lain, dan egois. Dengan kata lain, kurangnya

${ }^{16}$ Izzat Iwadh Khalifah, Kiat Mendidik Anak, terjemahan Rahmad Nurhadi, Jakarta: Pustaka Qalam, 2004, hlm. 17. kasih sayang yang duiperoleh anak dari orang tuanya dapat mengganggu perkembangan sosial anal dan juga penyesuaian dirinya. ${ }^{17}$

Demikian pentingnya memberikan kasih sayang dalam pendidikan anak, sehingga perlu langkah-langkah yang konkrit dalam mewujudkannya. Kasih sayang yang diberikan orang tua kepada anaknya bersifat kodrat, murni, dan tulus. Perwujudan kasih sayang ini dapat terlihat dalam kehangatan komunikasi antara orang tua dan anak. Dalam kaitan dengan hal ini, Jalaluddin Rahmat berpendapat bahwa kasih sayang itu harus dikomunikasikan. Kasih sayang tidak boleh disimpan saja dalam hati. Oleh karena itu, Nabi saw. mengungkapkan kasih sayangnya tidak saja secara verbal (dengan kata-kata), tetapi juga dengan perbuatan. Jalaluddin Rakhmat berpandangan, "Jika anak dibesarkan dengan kasih sayang dan persahabatan, ia belajar menemukan cinta dalam kehidupan, yang natinya bermanfaat bagi dirinya dan orang lain". ${ }^{18}$

Kehidupan suami-istri adalah kehidupan yang berpeluang mengalami kesulitan-kesulitan seperti beban pekerjaan yang memberatkan, pemenuhan nafkah, pendidikan anak, dan lain-lain. Saling tolong-menolong akan dapat meringankan beban satu sama lainnya. Pada saat suami tidak dapat menyediakan pembantu rumah tangga, ia dengan rela membantu pekerjaan rumah tangga jika istrinya kewalahan melakukannya. Rasulullah saw. terbiasa menjahit sendiri bajunya yang robek dan memperbaiki sandalnya yang rusak tanpa memberatkan istri-istrinya. Begitu juga istri, pada saat suami mengalami kesulitan dalam pemenuhan nafkah untuk keluarga,

${ }^{17}$ Zakiah Darajat, Berawal dari Keluarga: Revolusi Belajar Cara al-Qur'an. Jakarta: Hikmah, 2003, hlm. 45

${ }^{18}$ Jalaluddin Rakhmat, Islam Aktual: Refleksi Sosial Seorang Cendikiawan Muslim, Bandung, Mizan, 1996, cetakan ke-9, hlm. 186-187. 
tidak ragu-ragu untuk membantu dan meringankan suaminya. Namun, perlu dipahami, saling tolong-menolong bukan berarti kewajiban masing-masing dapat saling dipindahkan atau dihilangkan, misalnya suami mengurus rumah dan istri mencari nafkah. Sikap tolong menolong antara suami-istri akan semakin mempererat persahabatan di antara keduanya.

Merawat cinta kasih dalam keluarga ibaratnya seperti merawat tanaman, maka pernikahan dan cinta kasih harus juga dirawat agar tumbuh subur dan indah, di antaranya dengan mu'âsyarah bi al-ma'rûf. Rasulullah saw menyatakan bahwa, "Sebaik-baik orang di antara kamu adalah orang yang paling baik terhadap isterinya, dan aku (Rasulullah) adalah orang yang paling baik terhadap isteriku". (HR.Thabrani \& Tirmidzi).

3. Saling Terbuka (Mushârohah), Santun dan Bijak (Mu'âsyarah bil Ma'rûf)

Secara fisik suami isteri telah dihalalkan oleh Allah SWT untuk saling terbuka saat jima', padahal sebelum menikah hal itu adalah sesuatu yang diharamkan. Maka hakikatnya keterbukaan itu pun harus diwujudkan dalam interaksi kejiwaan (syu'ur), pemikiran (fikrah), sikap (mauqif), dan tingkah laku (akhlâq), sehingga masing-masing dapat secara utuh mengenal hakikat kepribadian suami-isterinya dan dapat memupuk sikap saling percaya (tsiqoh).

Hal itu dapat dicapai bila suami/isteri saling terbuka dalam segala hal menyangkut perasaan dan keinginan, ide dan pendapat, serta sifat dan kepribadian. Jangan sampai terjadi seorang suami/isteri memendam perasaan tidak enak kepada pasangannya karena prasangka buruk, atau karena kelemahan/kesalahan yang ada pada suami/isteri. Jika hal yang demikian terjadi hal yang demikian, hendaknya suami/isteri segera introspeksi (bermuhâsabah) dan mengklarifikasi penyebab masalah atas dasar cinta dan kasih sayang, selanjutnya mencari solusi bersama untuk penyelesaiannya. Namun apabila perasaan tidak enak itu dibiarkan maka dapat menyebabkan interaksi suami/isteri menjadi tidak sehat dan potensial menjadi sumber konflik berkepanjangan.

Sikap yang santun dan bijak dari seluruh anggota keluarga dalam interaksi kehidupan berumah tangga akan menciptakan suasana yang nyaman dan indah. Suasana yang demikian sangat penting untuk perkembangan kejiwaan (maknawiyah) anak-anak dan pengkondisian suasana untuk betah tinggal di rumah. Ungkapan yang menyatakan "Baiti Jannati" (Rumahku Syurgaku) bukan semata dapat diwujudkan dengan lengkapnya fasilitas dan luasnya rumah tinggal, akan tetapi lebih disebabkan oleh suasana interaktif antara suami-isteri dan orang tua-anak yang penuh santun dan bijaksana, sehingga tercipta kondisi yang penuh keakraban, kedamain, dan cinta kasih.

Sikap yang santun dan bijak merupakan cermin dari kondisi ruhiyah yang mapan. Ketika kondisi ruhiyah seseorang labil maka kecenderungannya ia akan bersikap emosional dan marah-marah, sebab syetan akan sangat mudah mempengaruhinya. Oleh karena itu Rasulullah saw. mengingatkan secara berulang-ulang agar jangan marah (lâ tagdlob). Bila muncul amarah karena sebab-sebab pribadi, segeralah menahan diri dengan beristigfar dan mohon perlindungan Allah (ta'awudz bi(a)llâh), bila masih merasa marah hendaknya berwudlu dan mendirikan shalat. Namun bila muncul marah karena sebab orang lain, berusahalah tetap menahan diri dan berilah ma'af, karena Allah menyukai orang yang suka mema'afkan. Bila karena sesuatu hal, suami/istri telanjur marah 
kepada anak/isteri/suami, segeralah minta ma'af dan berbuat baiklah sehingga kesan (atsar) buruk dari marah dapat hilang. Sesungguhnya dampak dari kemarahan sangat tidak baik bagi jiwa orang yang marah dan yang dimarahi.

\section{Komunikasi dan Musyawarah}

Pernikahan adalah menyatukan dua orang yang berasal dari latar belakang yang berbeda dan dua keluarga yang berbeda. Karena itu, suam-istri perlu saling memahami kelebihan dan kekurangan masing-masing, serta menerimanya dengan lapang dada tanpa ada penyesalan yang berkepanjangan. Kadangkala suami mempunyai kelebihan dalam kemampuan berkomunikasi, sedangkan istrinya kurang. Sebaliknya, istri memiliki kemampuan manajemen, sedangkan suaminya lemah. Kelebihan yang ada pada salah satu pasangan tidak menunjukkan ketinggian orang tersebut, demikian juga kekurangan yang ada pada seseorang tidak menunjukkan dia rendah. Tinggirendahnya manusia di sisi Allah Swt. adalah karena ketakwaannya seperti digariskan dalam QS al-Hujurat [49]: 13).

Saling memahami akan menjadikan suami-istri berempati terhadap pasangannya sehingga tidak mudah saling berburuk sangka. Sikap saling empati/memahami tidak berarti toleran terhadap kesalahan dan kelemahan yang dapat merugikan pasangannya. Namun, sikap ini memudahkan suami-istri untuk berpikir jernih sebelum memberikan pendapat, kesimpulan maupun penilaian. Kejernihan berpikir akan dapat memudahkan seseorang untuk bersikap dengan tepat dan benar terhadap pasangannya. Dengan itu, masing-masing akan terhindar dari kesalahpahaman yang memunculkan perselisihan dan pertengkaran. Keluarga sangat besar pengaruh dan peranannya dalam mewujudkan komunikasi yang hangat antara orang tua dan anak, terutama peran ayah (suami). Dalam keluarga sakinah, seorang ayah adalah ia yang mempu mewujudkan suasana keluarga yang harmonis dan komunikatif, sehingga tercipta komunikasi yang dialogis antara orang tua dan anak. Menurut Hasan Basri, komunikasi dalam keluarga memeiliki beberapa fungsi. Pertama, sarana untuk mengungkapkan kasih sayang; kedua, media untuk menyatakan penerimaan atau penolakan atas pendapat yang disampaikan; ketiga, sarana untuk menambah keakraban hubungan sesame anggota keluarga; dan keempat, menjadi barometer bagi baik-buruknya kegiatan komunikasi dalam sebuah keluarga. ${ }^{19}$

Dengan demikian, komunikasi yang baik dapat melahirkan hubungan yang baik pula. Sehingga dari sinilah dapat diperoleh keuntungan yang luas dalam kehidupan keluarga, seperti keutuhan keluarga, kasih sayang dan tanggung jawab yang semakin bertambah besar, prestasi belajar anak yang semakin membaik, tarap kesehatan mental keluarga, semangat kerja pergaulan sosial, kepuasa hubungan suami istri, dan hubungan emosional anggota keluarga yang semakin kuat, serta taraf kemampuan dalam menghadapi persoslan keluarga dan kehidupan pada umumnya yang semakin kompleks. ${ }^{20}$ Terciptanya komunikasi yang dialogis terhadap anak tergantung kepada bagaimana pola hubungan atau pola asuh orang tua terhadap anak. Dalam hal ini ada beberapa pendapat para ahli tentang pola hubungan atau pola asuh keluarga yang secara garis besar dapat dilihat dari tiga tipe keluarga, yaitu 1) keluarga koersif ${ }^{21}$

\footnotetext{
${ }^{19}$ Hasan Basri, Keluarga Sakinah: Tinjauan Psikologi dan Agama, Yogyakarta, Pustaka Pelajar, 1995, hlm. 80.

${ }^{20}$ Hasan Basri, Keluarga Sakinah: Tinjauan Psikologi dan Agama, hlm. 80.

${ }^{21}$ Pola Asuh koersif identik dengan hukuman dan pujian. Jika anak berlaku tidak sesuai dengan arahan orangtua, maka yang mereka terima ialah hukuman. Sebaliknya, jika sang anak berlaku sesuai
} 
atau otoriter, dan 3) keluarga permissive $\mathrm{e}^{22}$ atau laissez fair, dan 3) keluarga dialogis dan demokratis. ${ }^{23}$ Dari ketiga tipe tersebut, perkembangan anak akan lebih luwes dan dapat menerima kekuasaan secara rasional, apabila anak dibesarkan dalam keluarga yang diliputi oleh suasana yang dialogis dan demokratik. Dalam pola asuh ini, orang tua menanamkan harapannya dengan cara berbicara dari hati ke hati, serta menjelaskan pertimbangan keinginan mereka pada anak-anak. Karena adanya hubungan egaliter yang dibangun, anakanak terlatih untuk menjadi jujur, kritis, dan terbuka terhadap lingkungan sekitarnya. Sementara itu, pola asuh permisif, alih-alih, membuat mereka mandiri, orang tua justru terlalu menyerahkan anak pada dunia yang sedang berputar. Anak, terkadang menjadi merasa tidak diperhatikan, tidak diberikan bibit harapan, serta menganggap orang tua menganggap mereka tidak berarti. Dengan kata lain, dalam pola asuh yang demokratis akan tercipta komunikasi yang dialogis antara anak dan orang tua serta adanya kehangatan yang membuat anak merasa diterima oleh orang tua sehingga ada pertautan perasaan. Sebaiknya orang tua yang bersikap otoriter dan memberikan

dengan arahan orangtua, maka mereka akan menerima pujian. .

${ }^{22}$ Tipe pola asuh permisif merupakan antitesis dari pola asuh koersif. Orangtua permisif biasanya menghendaki anak-anak tumbuh dengan mandiri. Alih-alih membuat mereka mandiri, orangtua justru terlalu menyerahkan anak pada dunia yang sedang berputar. Anak, terkadang menjadi merasa tidak diperhatikan, tidak diberikan bibit harapan, serta menganggap orangtua menganggap mereka tidak berarti.

${ }^{23}$ Pola asuh ini menyeimbangkan kebebasan dan keteraturan. Orangtua dialogis mampu memahami di wilayah mana saja mereka mengarahkan anak-anak, dan di wilayah mana saja mereka mengamanahkan kebebasan pada mereka. Orangtua dialogis mendewasakan anak-anak dengan melibatkan mereka bertukar pikiran dan mencari solusi suatu masalah bersama. kebebasan penuh akan mendorong anak untuk berprilaku agresif. ${ }^{24}$ Dalam alQur'an, pola hubungan demokratis telah diisyaratkan, seperti terlihat dalam surat alBaqarah (2): 233). Dan (QS Âli Imrân (3):159).

Kedua ayat di atas menyinggung persoalan musyawarah yang merupakan salah satu nilai demokrasi di samping nilai adil dan persamaan. Pada QS al-Baqarah (2) ayat 233 , dijelaskan tentang bagaimana seharusnya hubungan suami istri pada saat mengambil keputusan berkaitan dengan masalah keluarga dan anak-anak. Sedangkan pada QS Âli Imrân (3):159 dijelaskan tentang sikap-sikap yang harus diterapkan dalam musyawarah.

\section{Tasâmuh (Toleran) dan Pemaaf}

Dua insan yang berbeda latar belakang sosial, budaya, pendidikan, dan pengalaman hidup bersatu dalam pernikahan, tentunya akan menimbulkan terjadinya perbedaan-perbedaan dalam cara berfikir, memandang suatu permasalahan, cara bersikap/bertindak, juga selera (makanan, pakaian, dsb). Potensi perbedaan tersebut apabila tidak disikapi dengan sikap toleran (tasamuh) dapat menjadi sumber konflik/perdebatan. Oleh karena itu masing-masing suami/isteri harus mengenali dan menyadari kelemahan dan kelebihan pasangannya, kemudian berusaha untuk memperbaiki kelemahan yang ada dan memupuk kelebihannya. Layaknya sebagai pakaian maka suami/isteri harus mampu mempercantik penampilan, artinya berusaha memupuk kebaikan yang ada (capacity building); dan menutup aurat artinya berupaya meminimalisir kekurangan yang ada (seperti yang Allah sebutkan dalam QS. Al-Baqarah (2):187).

Sikap toleran juga menuntut adanya sikap mema'afkan. Sikap ini meliputi 3

${ }^{24}$ Zakiyah Darajat, Berawal dari Keluarga: Revolusi Belajar Cara al-Qur'an,hlm. 50. 
(tiga) tingkatan, yaitu: (1) al-'afwu yaitu mema'afkan orang jika memang diminta, (2) al-shafhu yaitu mema'afkan orang lain walaupun tidak diminta, dan (3) almaghfirah yaitu memintakan ampun pada Allah untuk orang lain. Dalam kehidupan rumah tangga, seringkali sikap ini belum menjadi kebiasaan yang melekat, sehingga kesalahan-kesalahan kecil dari pasangan suami/isteri kadangkala menjadi awal konflik yang berlarut-larut. Tentu saja "mema'afkan" bukan berarti "membiarkan" kesalahan terus terjadi, tetapi mema'afkan berarti berusaha untuk memberikan perbaikan dan peningkatan.

Hubungan komunikatif, dialogis, dan musyawarah yang harus dikedepankan dalam keluarga harus dilandasi pula oleh dua sikap dasar, yaitu sikap lemah lembut dan pemaaf sebagaimana tercermin dalam QS. al-Baqarah (2):233 dan QS Âli Imrân (3):159. Pertama, yaitu sikap lemah lembut. Keluarga sakinah adalah keluarga harmonis yang menerapkan sikap lemah lembut dalam bermusywarah. Sebab sikap ini sangat besar pengaruhnya terhadap perkembangan anak. Umumnya anak-anak yang hidup dalam keluarga yang menerapkan prinsip-prinsip demokrasi cenderung memiliki harga diri yang tinggi, percaya diri, mudah memneraima kritikan, mandiri, dan optimis. ${ }^{25}$ Hal ini berbeda dengan anak yang hidup dalam suasana keluarga yang otoriter dalam arti bahwa orang tua selalu memaksakan kehendak, bersikap keras dan kasar serta tidak memberikan kesempatan kepada anak untuk ikut dalam menetapkan sikapnya, maka anak tersebut, umumna, akan memiliki harga diri yang rendah, pesimis, tidak suka dikritik, dan tidak mandiri.

\footnotetext{
${ }^{25}$ Salah satu tujuan musyawarah dalam alQur'an adalah untuk mengangkat martabat seseorang. Lihat Muhammad Fakhr al-Dîn bin Dhiya al-Dîn al-Razi, Tafsîr al-Fakhr al-Râzî, Beirut, Dâr al-Fikr, 1994, jilid IX, hlm. 69.
}

Kedua, memberi maaf dan membuka lembaran baru. Maaf secara harfiah berarti menghapus. Dengan demikian, memaafkan berarti menghapus bekas luka di ahti akibat perlakuan pihak lain yang dinilai tidak wajar. Hal ini berarti bahwa dalam berkomunikasi khususnya dalam bermusyawarah dibutuhkan sikap pemaaf dengan tidak membesar-besarkan hal yang sepele yang dilakukan oleh anggota keluarga. Kehidupan suami-istri tidak luput dari berbagai kelemahan, kesalahpahaman dan pertengkaran kecil. Hal-hal ini akan dapat merenggangkan hubungan persahabatan satu sama lain. Pada saat salah seseorang dari suami-istri melakukan sesuatu hal yang menimbulkan kemarahan, maka langkah yang perlu disuburkan oleh yang lainnya adalah menahan marah dan mudah saling memaafkan. Saling memaafkan satu sama lainnya adalah kunci untuk memelihara persahabatan antara suami-istri.

Dalam kaitan dengan hal ini, orang tua sebagai soko guru keluarga sebaiknya mau menolelir dan menjelaskan kesalahankesalahan anak secara positif. Terlebih jika kesalahan itu dilakukan untuk pertama kalinya. Melakukan pengawasan terhadap kesalahan-kesalahan yang sifatnya sederhana akan menciptakan kegelisahan, ketegangan, dan menimbulkan tidak adanya saling percaya dalam hubungan orang tua dan anak. Sebaliknya sikap tolelir dan bijaksana mampu mengarahkan kesalahan tersebut menjadi nilai positif bagi anak. Di sisi lain, anak akan berusaha untuk lebih memberikan perhatian dan merasa senang untuk mendengarkan komentar yang diberikan oleh mereka yang lebih dewasa. ${ }^{26}$ Dalam al-Qur'an, Allah berfirman: "Dan kalau Sekiranya Allah menyiksa manusia disebabkan usahanya, niscaya Dia tidak akan meninggalkan di atas permukaan bumi suatu mahluk yang

\footnotetext{
${ }^{26}$ Izzat Iwadh Khalifah, Kiat Mendidik Anak,
} hlm. 143 . 
melatapun akan tetapi Allah menangguhkan (penyiksaan) mereka, sampai waktu yang tertentu; Maka apabila datang ajal mereka, Maka Sesungguhnya Allah adalah Maha melihat (keadaan) hamba-hamba-Nya (QS Fâthir (35):45).

\section{Adil dan Persamaan}

Sikap adil merupakan factor yang harus muncul dalam keluarga sakinah. Adil berarti seimbang dan proporsional. Dengan demikian, keadilan dapat diartikan sebagai keseimbangan, tidak berat sebelah, tidak pilih kasih, tidak diskriminatif, dan memenuhi aspek pemenuhan kebutuhan berdasarkan proporsi dan kebutuhan masing-masing. Kata adil merupakan kata serapan dari bahasa Arab yaitu 'âdil. Di dalam al-Qur'an, pengertian adil tidak hanya ditunjukkan oleh kata 'âdil tetapi juga ditunjukkan oleh kata qist. Dalam bahasa Inggris kata adil dapat diterjemahkan menjadi kata just atau justice.

Sikap adil mempunyai peran besar Berlaku adil terhadap anak-anak dan memperlakukan mereka secara sama tanpa pilih kasih dapat menjadikan anak tumbuh sehat dan jauh dari sifat iri hati, dengki, dan dendam. Oleh karena itu, Islam mewajibkan untuk bersikap adil kepada anka-anak, sekaligus melarang untuk melebeih-lebihkan dan mengutamakan salah satu dari anak-anak. Sebab hal itu dapat menjerumuskan mereka kepada perbuatan durhaka, di samping dapat merusak tali silaturahmi. Dalam al-Qur'an telah digambarkan bagaimana bahaya yang ditimbulkan oleh perasaan didiskriminasikan antar saudara, seperti dalam surat Yusuf (12) ayat 8 yang menceritakan ucapan saudara-saudara Yusuf 'alaihi salâm:"(Yaitu) ketika mereka berkata, "Sesungguhnya Yusuf dan saudara kandungnya (Bunyamin) lebih dicintai oleh ayah kita dari kita sendiri, padahal kita (ini) adalah satu golongan (yang kuat).
Sesungguhnya ayah kita adalah dalam keliruan yang yang nyata (QS Yusuf (12):8)

Perasaan iri, dengki, dan dendam saudara-saudara Yusuf a.s. telah mengantarkan mereka untuk melakukan perbuatan yang merugikan dan mencenderai hak dan kewajiban persaudaraan dan keluarga mereka sendiri: "Bunuhlah Yusuf atau buanglah dia ke suatu daerah (yang tak dikenal) supaya perhatian ayahmu tertumpah kepadamu saha, dan sesudah itu hendaklah kamu menjadi orang-orang yang baik (QS Yusuf (12):9

Kisah ini menjadi salah satu bukti tentang pentingnya prinsip dan pemenuhan rasa keadilan dalam keluarga, sehingga tidak aneh jika Rasulullah saw. sebagai sosok pendidik awal umat manusia mendorong para orang tua untuk dapat mewujudkan prinsip keadilan antar anak. Bahkan Rasulullah menolak keras dan mengingkari perilaku tidak adil terhadap anak-anak. Dalam salah satu haditsnya Rasulullah bersabda:

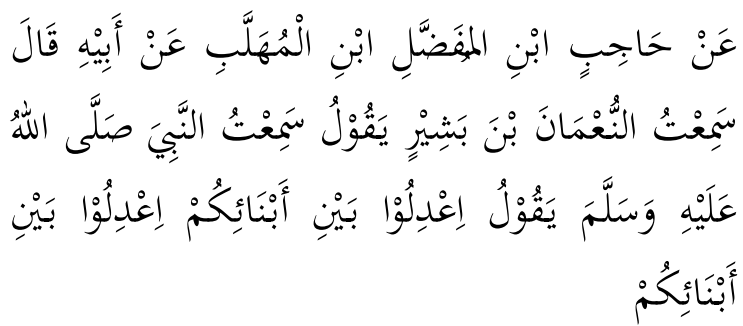

Hajib bin al-Mufadhdhal bin al-Muhallab dari bapaknya, ia berkata, "Aku mendengar al-Nu'man bin Basyir berkata dalam khutbahnya, 'Rasulullah saw. bersabda, 'Berlakulah adil kepada anakanakmu, berlakulah adil kepada anakanakmu, berlakulah adil kepada anakanakmu (H.R. al-Nasâi). ${ }^{27}$

Lebih lanjut Rasulullah menjelaskan bahwa berlaku adil kepada anak merupakan salah satu cara untuk membuat anak mau berbuat baik kepda orang tua.

${ }^{27}$ Al-Nasâi, Sunan al-Nasâi, Kitâb al-Nahl, Beirut, Dâr al-Fikr, 1930, jilid III, hlm. 262. 
Rasulullah menjanjikan bagi orang tua seperti ini akan dirahmati oleh Allah seperti sabdanya, "Allah merahmati orang tua yang membantu anaknya untuk berbuat baik kepadanya". ${ }^{28}$ Pada gilirannya, situasi ini akan mewariskan kegemaran untuk permusuhan, persaingan tidak sehat, pertengkaran, dan rusaknya tali silaturahmi (persaudaraan dan kekeluargaan) pada diri anak. Karena itu, Islam mewajibkan untuk bersikap adil kepada anak-anak dan melarang perilaku membeda-bedakan dan melebihkan salah satu dari mereka, baik dalam masalah pemberian maupun kepemilikan.

\section{Sabar dan Syukur}

Dengan kesadaran awal bahwa suami/istri dan anak-anak dapat berpeluang menjadi musuh, maka sepatutnya suami/istri berbekal diri dengan kesabaran (QS al-Taghâbun (64):14). Bagian dari kesabaran adalah keridhaan menerima kelemahan/kekurangan pasangan suami/isteri yang memang diluar kesanggupannya. Penerimaan terhadap suami/isteri harus penuh sebagai satu "paket", dia dengan segala hal yang melekat pada dirinya, adalah hal yang harus diterima secara utuh. Begitupun penerimaan orang tua kepada anak-anak dengan segala potensi dan kecenderungannya. Kesabaran dalam kehidupan rumah tangga merupakan hal yang fundamental (asâsî) untuk mencapai keberkahan, sebagaimana ungkapan berikut: "Pernikahan adalah fakultas kesabaran dari universitas Kehidupan". Mereka yang lulus dari fakultas kesabaran akan meraih banyak keberkahan.

Syukur juga merupakan bagian yang tak dapat dipisahkan dalam kehidupan berumah tangga. Rasulullah mensinyalir bahwa banyak di antara penghuni neraka

${ }^{28}$ HR Ibn Abi Syaiban dalam al-Mushannaf, dikutip dari Izzat Iwadh Khalifa, Kiat Mendidik Anak hlm. 51. adalah kaum wanita, disebabkan mereka tidak bersyukur kepada suaminya. Mensyukuri rezeki yang diberikan Allah lewat jerih payah suami seberapapun besarnya dan bersyukur atas keadaan suami tanpa perlu membandingbandingkan dengan suami orang lain, adalah modal mahal dalam meraih keberkahan; begitupun syukur terhadap keberadaan anak-anak dengan segala potensi dan kecenderungannya, adalah modal masa depan yang harus dipersiapkan. Dalam keluarga harus dihidupkan semangat "memberi" kebaikan, bukan semangat "menuntut" kebaikan, sehingga akan terjadi surplus kebaikan. Inilah wujud tambahnya kenikmatan dari Allah.

Mensyukuri kehadiran keturunan sebagai karunia Allah, harus diwujudkan dalam bentuk mendidik mereka dengan pendidikan Rabbani sehingga menjadi keturunan yang menyejukkan hati. Keturunan yang mampu mengemban misi risalah dien ini untuk masa mendatang, maka jangan pernah bosan untuk selalu memanjatkan do'a: $Y a$ Rabb kami karuniakanlah kami isteri dan keturunan yang sedap dipandang mata, dan jadikanlah kami pemimpin orang yang bertaqwa. Ya Rabb kami karuniakanlah kami anak-anak yang sholeh. Ya Rabb kami karuniakanlah kami dari sisi Engkau keturunan yang baik.Ya Rabb kami karuniakanlah kami dari sisi Engkau keturunan yang Engkau Ridha-i.Ya Rabb kami jadikanlah kami dan keturunan kami orang yang mendirikan shalat.

Do'a diatas adalah ungkapan harapan para Rasul tentang sifat-sifat (muwashshofât) ketuturunan (dzurriyât) yang diinginkan. ${ }^{29}$ Pada intinya keturunan yang diharapkan adalah keturunan yang

${ }^{29}$ Lihat juga dalam sebagaimana diabadikan Allah dalam al-Qur'an (QS. Al-Furqon:74; QS. Ash-Shaafaat: 100; QS. Al-Imran:38; QS. Maryam: 5-6; dan QS. Ibrahim:40) 
sedap dipandang mata (Qurrota a'yun), yaitu keturunan yang memiliki sifat penciptaan jasad yang sempurna (thoyyiba), ruhaniyah yang baik (shâlih/ah), diridhai Allah karena misi risalah agama yang diperjuangkannya (wali radhi), dan senantiasa dekat dan bersama Allah (muqîm al-shalâh).

Demikianlah hendaknya harapan orang tua terhadap anak, agar mereka memiliki karakteristik (muwashofât) tersebut, di samping upaya (ikhtiâr) orang tua memilihkan guru/sekolah yang baik, lingkungan yang sehat, makanan yang halal dan baik (thoyyib), fasilitas yang memadai, keteladanan dalam keseharian, dsb; hendaknya orang tua selalu memanjatkan do'a tersebut.

\section{Kesimpulan}

Dengan demikian, menurut penulis, terdapat faktor-faktor lain yang menjadi karakteristik dari keluarga sakinah, yaitu 1) Lurusnya Niyat (Islâh al-Niyyah) dan Kuatnya hubungan dengan Allah (Quwwatu shilah billâh), 2) kasih sayang; 3) saling Terbuka (Mushârohah), Santun dan Bijak (Mu'asyarah bil Ma'rûf); 4) komunikasi dan musyawarah, 5) Tasâmuh (Toleran) dan Pemaaf; 6) adil dan persamaan; 7). Sabar dan syukur. Secara umum dapat dikatakan bahwa keluarga sakinah dibangun di atas kasih sayang yang mengedepankan aspek komunikasi dan musyawarah sebagai bentuk dari pola hubungan demokratis yang menjadi sarana bagi terwujudnya komunikasi dialogis. Sehingga dengan adanya komunikasi tersebut tercapailah ketenangan, kedamaian, dan ketentraman dalam rumah tangga. Sedangkan musyawarah yang dipakai adalah musyawarah yang dihiasi dengan sikap lemah lembut, pemberi maaf, serta mengedepankan aspek keadilan dan persamaan. Beberapa konsep dasar di atas akan dijelaskan secara rinci di bawah ini.

\section{DAFTAR PUSTAKA}

Al-Qur'an al-Karim.

Abrasyi, Muhammad Athiyyah al-. 2003. Prinsip-Prinsip Dasar Pendidikan Islam, terjemahan abdullan Zakiy alKaaf, Bandung, Pustaka Setia.

Agustian, Ari Ginanjar. 2001. ESQ: Rahasia Sukses Membangun Kecerdasan. Jakarta: Arga.

Ahmadi, Abu. 2001. Ilmu Pendidikan. Jakarta: PT Rineka Cipta.

Aly, Haery Nur. 1999. Ilmu Pendidikan Islam. Jakarta: Logos. cet. Ke-2.

Arid, Ali Hasan al-. 1992. Sejarah dan Metodologi Tafsîr. Jakarta: Rajawali Press.

Arifin, H. M. 1994. Filsafat Pendidikan Islam. Jakarta: Bina Aksara.

Atho, Nafisul dan Fahruddin, Arif. 2003. Hermeneutika Transedental. Yogyakarta: IRCISoD.

Azra, Azyumardi. 1999. Pendidikan, Tradisi, dan Modernitas Menuju Milenium Baru. Jakarta: Logos..

Baihaqi A.K. 1996. Mendidik Anak Dalam Kandungan. Jakarta: Raja Grafindo Persada.

Baidan, Nasruddin. 1998. Metodologi Penafsiran al-Qur'an. Yogyakarta: Pustaka Pelajar.

Bukhari, al-. T.T. Shahîh Bukhari: Kitâb al-Janâiz. Kairo: Dâr al-Hadîts.

Covey, Stephen R. 1995. The Seven Habits of Highly Effective People. The Gisinnes Library.

Covey, Stephen R. 2004. The $8^{\text {th }}$ Habit. The Gisinnes Library.

Darajat, Zakiyah. 1980. Kepribadian Guru. Jakarta: Bulan Bintang. 
Darajat, Zakiyah. 1996. Ilmu Pendidikan Islam. Jakarta: Bumi Aksara.

Darajat, Zakiyah. 2003. Berawal dari Keluarga: Revolusi Belajar Cara alQur'an. Jakarta: Hikmah.

Dimyati dan Mudjiyono. 2002. Belajar dan Pembelajaran. Jakarta: Rineka Cipta dan Depdikbud.

Dryden, Gordon dan Vos, Jeannette. 2000. Revolusi Cara Belajar. Bandung: Kaifa.

Faiz, Fahruddin. 2002. Hermeneutika alQur'an. Yogyakarta:Qalam.

Farmawî, al-. 1993. al-Bidayah fi Tafsir alMaudhu'i, Liban: Dâr al-Hadîts.

Goleman, Daniel. 1999. Kecerdasan Emosi untuk Mencapai Prestasi Puncak. Jakarta:Gramedia Pustaka Utama.

Goleman, Daniel. Kecerdasan Emosional: Mengapa EI Lebih Penting daripada IQ. Jakarta: Gramedia Pustaka Utama.,

Gottman, John. 1998. Kecerdasan Emosional: Kiat-Kiat Membesarkan Anak yang Memiliki Kecerdasan Emosional. Jakarta: Gramedia.

Hadjar, Ibnu. 1996. Dasar-Dasar Metodologi Penelitian Kwantitatif dalam Pendidikan. Jakarta: Rajawali Press.

Hamka. 1982. Tafsir al-Azhar. Jakarta: Panjimas.

Hammad, Suhailah Zainul Abidin . 2002. Menuai Kasih Sayang di Tengah Keluarga, terjemahan Ayub Muraslin. Jakarta: Mustaqim.

Hasan, Yusuf Muhammad al-. 1998. Pendidikan Anak dalam Islam. Jakarta: Darul Haq.

Hidayat, Komaruddin. 1996. Memahami Bahasa Agama. Jakarta: Paramadina.
Jalaluddin, H. 2001. Teologi Pendidikan. Jakarta: Raja Grafindo Persada.

Katsîr, Ibn. 1986. Tafsîr al-Qur'ân al'Adzîm. Beirut Dâr al-Fikr

Khalifah, Izzah Iwadh. 2004. Kiat Mendidik Anak. Terjemahan Rahmat Nurhadi. Jakarta: Pustaka Islami.

Langulung, Hasan. 1995. Manusia dan Pendidikan: Suatu Analisis Psikologi dan Pendidikan. Jakarta: Pustaka alHusna.

Moleong, Lexy. 2005. Metodologi Penelitian Kualitatif. Bandung: Rosda Karya.

Muslim. T.T. Shahîh Muslim: Kitâb alQadr. Kairo: Dâr al-Hadîts.

Muhajdir, Noeng. 1998. Metodologi Penelitian Kualitatif. Yogyakarta: Raka Sarasin.

Mulyana, $\quad$ Rohmat. 2004. Mengartikulasikan Pendidikan Nilai. Bandung: Alfabeta.

Nahlawi, Abd al-Rahmân al-. 1995. Pendidikan Islam di Rumah, Sekolah, dan Masyarakat. Terjemahan oleh Sihabuddin. Jakarta: Gema Insani Press.

Nggermanto, Agus. 2005. Quantum Quotien. Bandung: Nuansa.

Pasiak, Taufik. 2002. Revolusi IQ/EQ/SQ: Antara Neurosains dan Al-Qur'an. Bandung: Mizan.

Porter, Bobbi De dan Hernacki, Mike. 1999. Quantum Leraning. Bandung:Kaifa.

Purwanto, Ngalim. 2003. Psikologi Pendidikan. Bandung: Rosdakarya

Rusmana, Dadan. 2005. Tokoh dan Pemikiran Semiotika Kontemporer. Bandung: Tazkiya Mandiri Utama.

Sabri, Alisuf. 1999. Ilmu Pendidikan Islam. Jakarta: Pedoman Ilmu Jaya. 
Shihab, Quraish. 2002. Membumikan alQur'an: Fungsi dan Peran wahyu dalam Kehidupan Masyarakat. Bandung: Mizan.

Sobur, Alex. 2004. Analisis Teks Media. Bandung: Rosda Karya.

Sonneman, Milly R.. 2002. Mahir Berbahasa Visual, Bandung: Kaifa.

Syah, Muhibbin. 1997. Psikologi Pendididikan dengan Pendekatan Baru. Bandung: Rosda Karya.

Syahidin. 2001. Metode Pendidikan Qur'ani: Teori dan Aplikasi. Jakarta: Misaka Galiza.

Syirbashi, Ahmad. 1996. Sejarah Tafsir alQur'an. Jakarta: Pustaka al-Husna.

Tasmara, Toto. 2001. Kecerdasan Ruhaniah, Jakarta: Gema Insani Press.
Thabarî, Ibn Jarîr al-. 1988. Jami' alBayân fî̀ Ta'wîl al-Qur'ân. Beirut: Dâr al-Fikr.

Chabin Thaha. 1996. Kapita Selekta Pendidikan Islam. Yogyakarta: Pustaka Pelajar.

Tilaar, H.A.R. 2004. Paradigma Baru Pendidikan Nasiona. Jakarta: Rineka Cipta.

Wahjoetomo. 1997. Perguruan Tinggi Pesantren: Pendidikan Alternatif Masa Depan. Jakarta: Gema Insani Press.

Zohar, Danah dan Ian Marshal. 2001. SQ: Manfaatkan Kecerdasan Sipritual dalam Berpikir Integralistik dan Holistik untuk Memaknai Kehidupan. Bandung: Mizan. 
